\title{
O narrador em viagem ou o condenado a narrar
}

\author{
Cristiano Rodrigues Batista ${ }^{1}$
}

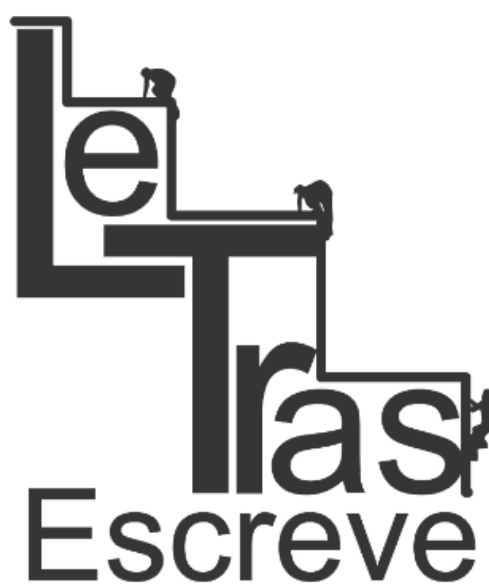

(ISSN 2238-8060)

Resumo: Este artigo pretende analisar a relação entre a viagem e o exercício poético em parte da obra do chileno Roberto Bolaño. É possível ver certa Enfermidade acompanhando a obra do escritor Roberto Bolaño. Para além de sua doença física, pela leitura de alguns de seus textos, vemos que é recorrente a luta contra essa Enfermidade, que também pode ser o sinônimo de "resignação". Identificada a doença, resta ir em busca do seu antídoto. A viagem é a busca do antídoto para quem está enfermo e essa busca também é, para Bolaño, o aprendizado pelo qual o poeta deve passar. Seguir viagem é, assim, um primeiro passo da busca da cura para a Enfermidade e em direção ao cumprimento das exigências postas para exercer legitimamente o ofício da literatura.

Palavras-chaves: Roberto Bolaño, exílio, viagem, Charles Baudelaire.

Abstract: This article aims to analyze the relationship between the trip and the poetic exercise in part of the chilean Roberto Bolaño work. You can see some distemper following the work of writer Roberto Bolaño. Apart from his physical illness, and by reading some of his texts, we see that recurs the fight against this distemper, which can also be synonymous with "resignation." Identified the disease, remains the necessity of going in search of its antidote. The journey is the search for the antidote for those who are sick, and this search is also learning by which the poet must pass. Next trip is thus a first step in the search for a cure for distemper and towards the fulfillment of the requirements placed to legitimately exercise the craft of literature.

Keywords: Roberto Bolaño, exile, trip, Charles Baudelaire.

\section{Introdução}

Roberto Bolaño é lido e estudado em seu país de origem, o Chile, no país em que viveu importantes anos de sua juventude, o México, em outros países da América Latina e também em parte da Europa e América do Norte. Assim como seus personagens que viajaram, exilaram-se, alguns voltando à terra natal, outros não, sua obra parece acompanhar certa mobilidade territorial, não só no que

\footnotetext{
${ }^{1}$ Doutorando em História e Teoria Literária pela Universidade Estadual de Campinas - UNICAMP. E-mail: cristianorodriguez@gmail.com.
}

https://periodicos.unifap.br/index.php/letras

Macapá, v. 6, n. I, Io semestre, 2016. 


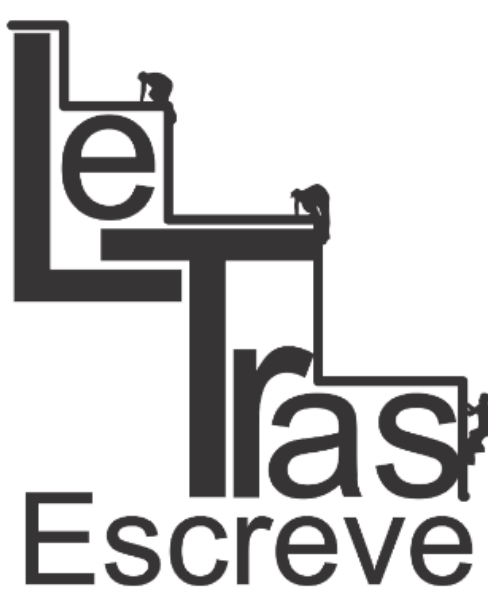

(ISSN 2238-8060) diz respeito ao alcance e à temática como também pela concepção narrativa de certas histórias.

Em seu texto "Literatura + enfermedad = enfermedad" 2 a princípio vemos que o que ele - o narrador que, no caso, coincide com o próprio Bolaño - chama de doença diz respeito à sua condição médica que exigia um transplante de fígado, para que houvesse alguma chance de sobreviver. No entanto, ao longo do texto, ao fazer uma leitura de Mallarmé, a doença a qual se refere pode ser vista como algo que vá além de uma condição fisiológica, "la enfermedad como resignación, resignación de vivir o resignación de lo que sea. Es decir [Mallarmé] está hablando de derrota." (Bolaño, 2012b, p. 145). À falta da vontade de ler e fazer sexo que advém dessa derrota, o narrador diz que Mallarmé deixa como única possibilidade a viagem: "navegar es necesario, vivir no es necesario". A liberdade do viajante seria um passo importante ao aprendizado poético, um verdadeiro (e possível) antídoto contra a resignação. Chegado a esse ponto do texto, Bolaño lembra do poema de Baudelaire "Le vouyage" que, segundo o chileno, pode ter sido a motivação para o soneto de Mallarmé. Bolaño aproxima o viajante do poema de Baudelaire ao condenado, que precisa renunciar a tudo para ser o viajante verdadeiro. Este não pode ter nada a perder para mergulhar em uma viagem até as últimas consequências.

A voz do poeta pergunta ao viajante o que ele viu e várias coisas são apresentadas. Segundo Bolaño, o viajante quer se salvar, mas só encontra:

Saber amargo, o que se tira de uma viagem! Monótono e pequeno, o mundo, sem remédio, Hoje, ontem, amanhã, nos faz ver nossa imagem, Um oásis de horror num deserto de tédio! (Baudeleire, 2006, p. 419-21)

${ }^{2}$ Bolaño, 2012b. 
Para Bolaño, esse é o diagnóstico mais lúcido da enfermidade do homem moderno. O saber amargo adquirido na viagem, a revolução, a morte, o tédio e a fuga são algumas das causas dessa doença da qual, não apenas o homem moderno, também sofrem os poetas. Mas será que o horror que cerca a modernidade possibilitaria somente a vida como um zumbi, nesse deserto de tédio, ou mesmo uma conversão em escravizador de um outro? Outra opção é apontada na última estrofe do poema,

Queremos, tal o cérebro nos arde em fogo,

Ir ao fundo do abismo, Inferno ou Céu, que importa?

Para encontrar no Ignoto o que ele tem de novo! (Baudelaire, 2006, p. 423)

Em parte afirmando a leitura de Baudelaire e já sabendo da

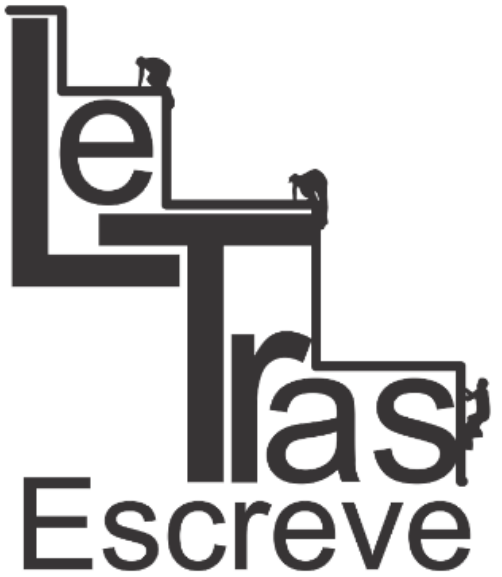

(ISSN 2238-8060)

Es decir, para el poeta de Igitur no sólo nuestros actos están enfermos sino que también lo está el lenguaje. Pero mientras buscamos el antídoto o la medicina para curarnos, lo nuevo, aquello que sólo se puede encontrar en lo ignoto, hay que seguir transitando por el sexo, los libros y los viajes, aun a sabiendas de que nos llevan al abismo, que es, casualmente, el único sitio donde uno puede encontrar el antídoto. (Baudelaire, 2012b, p. 156)

Só o caminho pelo desconhecido poderia trazer o novo do qual fala Bolaño a partir de Baudelaire e Mallarmé, que é o mesmo que dizer, poderia trazer a cura para a derrota que, de antemão, é bem conhecida. Apesar do fim da viagem estar posto na iminência da morte, o caminho que leva ao abismo é a única possibilidade de evitar que se passe a viver a morte que já lhe fora anunciada.

Pensando na obra ficcional de Bolaño iluminada pelo trecho citado, entendemos que a escritura do chileno é parte desse esforço que o leva ao abismo ou a instantâneos de personagens capturados transitando à beira desse abismo. Nos dois contos de Bolaño trabalhados a seguir, podemos ver como a sua narrativa se 
movimenta em uma busca por frágeis antídotos, ou antígenos contra enfermidades específicas, e estaciona em lugares-pessoas que the tragam vislumbres de cura e de vida. A viagem e o exílio passam a ser lugares de busca, estações de parada do viajante que está a procura do novo no desconhecido.

\section{O condenado a narrar}

"Você tem tempo para ouvir a minha história? Depende da história, falei, mas acho que sim" (Bolaño, 2012a, p. 87). A partir daí começa, verdadeiramente, a narrativa do conto "A neve", de Chamadas telefônicas. O narrador é chileno e encontra outro chileno, Rogelio Estrada, que viveu por muitos anos na Rússia. O encontro se dá em Barcelona, num bar da rua Tallers.

Após saber que o narrador também era chileno, Estrada foi cumprimentá-lo e uma noite convidou o narrador para que fosse à casa daquele. Lá se dá a conversa. Estrada era filho de um dos dirigentes do Partido Comunista do Chile. Com o golpe de Estado, a família de Roger Strada, como passou a ser conhecido, exilou-se na União Soviética. Desde o Chile, Estrada se interessava pela marginalidade, praticando pequenos furtos e não se encaixando nos lugares a ele designados. Em Moscou, juntou-se ao amigo Jimmy Fodeba, da República Centro-Africana, com trajetória semelhante de perseguição política vivida pelo pai de Estrada. Foram dois jovens perdidos que circulavam muito bem no submundo moscovita, acumulando algum dinheiro e tendo em comum o sonho de conhecer o mundo.

Eu, pelo contrário, me moldei à nova situação [O fim da União Soviética e início do período democrático] e decidi economizar dinheiro, agora que era possível, para cair fora de lá de uma vez por todas e começar a conhecer o mundo, Europa, África que, apesar da minha idade, já tinha mais de trinta e estava, como se diz, bem grandinho, eu imaginava como sendo o reino da aventura, uma fronteira sem limites, um novo conto infantil onde eu poderia começar de novo, ser feliz, encontrar a mim

https://periodicos.unifap.br/index.php/letras

Macapá, v. 6, n. I, Io semestre, 2016. 
mesmo, como dizíamos nós, guris de Santiago de 1973. (Bolaño, 2012a, p. 92)

Em Os detetives selvagens (2006) e em 2666 (2010), vemos jovens que também alimentam desejos de conhecer o mundo: no primeiro, podemos ver a deambulação de poetas, mais especificamente, nos personagens Ulises Lima e Arturo Belaño; no segundo, a movimentação e o fato de o escritor Benno von Archilmboldi figurar como alguém que não se pode localizar. Nesses personagens também podemos observar especial inclinação para estar à margem do estabelecido, do reconhecido, bem como de uma condição de exilado que passam a ocupar no desenvolvimento das narrativas.

Rogelio Estrada continua a contar como conheceu e começou

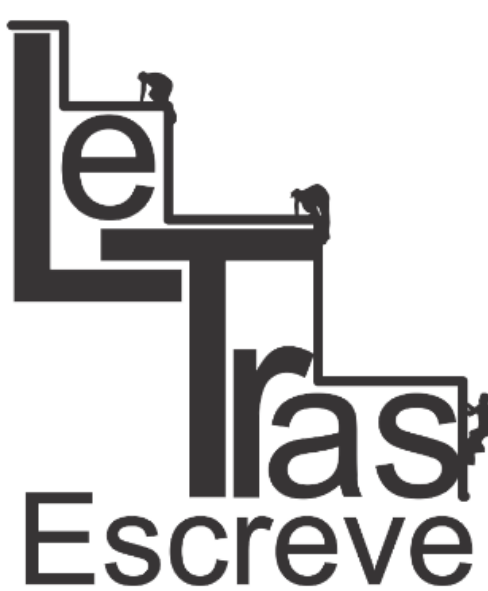

(ISSN 2238-8060) a trabalhar para Misha Pavlov, um chefe da máfia. O chileno trabalhava no ramo das apostas e no aliciamento de algumas atletas, que representavam a preferência do gângster moscovita no quesito amantes.

Uma dessas atletas, Natália Tchuikova, chamou especial atenção de Pavlov, além disso o próprio Estrada se apaixonou por ela. O relato continua e Estrada conta que matou Pavlov num momento em que pensou que que o gângster o mataria. Estrada fugiu da Rússia levando Natália. Moraram em Paris e na Alemanha, depois ela o deixou e ele foi para a Espanha.

Todo o relato de Estrada se desenvolve em um discurso indireto livre que se inicia logo após a pergunta sobre a possibilidade do narrador ouvir a história do chileno radicado em Moscou. Quase não há intervenções do narrador, o que pode indicar que o condicionamento imposto na resposta do narrador, sobre a disponibilidade de ouvir a história de Estrada, tenha se cumprido.

A partir da cessão de voz ao chileno radicado em Moscou, parece haver um reconhecimento da necessidade de que aquela história fosse narrada. Para a história de Rogelio, o narrador tem tempo para ouvir. O narrador se retira e a voz de Estrada ocupa o 
espaço narrativo. Rogelio precisou deixar seu país, lançou-se à viagem - primeiro com os pais, depois por sua conta -, desejando ir, quem sabe um dia, até a África. Procurava algo, que parece não ter encontrado.

Mas de noite, principalmente de noite, sinto saudade da Rússia e sinto saudade de Moscou. Aqui não é nada mal, mas não é a mesma coisa, se bem que se você me pedisse maior precisão não saberia te dizer de que sinto falta. A alegria de estar vivo? Não sei. Um dia destes vou tomar um avião e voltar para o Chile. (Bolaño, 2012a, p. 103)

Ao personagem a quem o narrador oferece o espaço da narrativa, parece restar o imperativo de seguir viagem. Apesar de não saber bem quem é - uma vez que queria encontrar a si mesmo - e de não saber bem do que está sentindo falta, ele termina seu relato deixando claro que há possibilidade de se colocar em movimento mais uma vez, talvez até a volta ao Chile. Talvez, haja até a necessidade de seguir viagem mais uma vez. Como vimos, seguir viagem aqui não deve ser lido apenas como a possível volta ao Chile, Estrada mostra sintomas da enfermidade que acomete ao homem moderno quando este sente falta da alegria de estar vivo. Seguir viagem é também retomar a busca por se sentir vivo.

\section{Sacrifício ritual}

No conto "Vagabundo na França e Bélgica", do volume Putas assassinas (2008), vemos o protagonista $B$, que pode coincidir com Belano d'Os detetives selvagens, ou mesmo com o próprio Bolaño. É em torno de $B$ que o conto irá se desenvolver. O início se dá com uma frase que indica um locomover-se de um país ao outro, apesar desta primeira frase apresentar somente o país de destino: "B entrou na França. Passa cinco meses andando por lá e gastando todo o dinheiro que tem. Sacrifício ritual, ato gratuito, aborrecimento" (Bolaño, 2008, p. 78). A ideia de um ritual que implique em um 


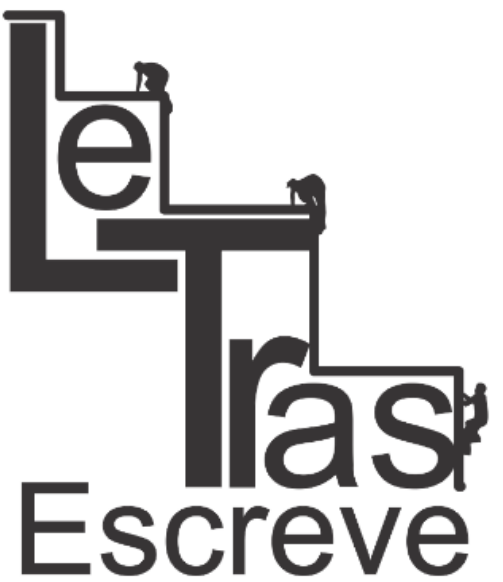

(ISSN 2238-8060)

sacrifício é posta sem maiores explicações. Deslocamento e ritual serão duas ideias importantes na progressão do conto.

Diante do "oásis de horror num deserto de tédio" que o viajante baudelairiano diz ter encontrado, Bolaño conclui, a partir de Mallarmé, que a única saída possível é seguir viagem em direção ao abismo. É por meio da viagem, dos livros e do sexo que se pode chegar ao único lugar onde seria possível encontrar o antídoto para a enfermidade do homem moderno, bem como para executar de forma legítima o ofício da literatura. O viajante verdadeiro precisa renunciar a tudo o que tem e manter-se em constante deslocamento. B leva a cabo tal sacrifício: passa meses andando e gastando o dinheiro que tem.

Após terminar de ler um romance, B encontra, num sebo, o volume 2 de Luna park, o número da revista é dedicado a grafias. Vários escritores colaboraram com o número e sobre cada um deles o narrador traz algum comentário, uma pequena biografia. $\mathrm{Na}$ verdade, há um escritor sobre quem $B$ não sabe nada, Henri Lefebvre. Tal nome se ilumina e ele compra a revista, à qual se dedica nos dias subsequentes entre várias atividades que parecem não chamar tanta atenção quanto a leitura da revista. Descobre que Lefebvre viveu infância e adolescência na Bélgica, que morreu em 1973 - sem deixar de lembrar que a data representa também o golpe no Chile -, suicidou-se, e que após a sua morte foram encontrados quinze quilos de manuscritos e desenhos.

Paris parece não interessar mais ao protagonista que decide ir à Bélgica. Lembra-se de uma amiga lá, uma filha de um exilado chileno com uma ugandense. Toma novamente o trem e, ao chegar, passeia pelo centro de Bruxelas. B encontra a sua amiga, apresentada como $\mathrm{M}$, conversam. Ele mostra a ela o trabalho de Lefebvre na revista. M conta um pouco de si para B.

Naquela manhã, quem fala do ser na realidade é M. Conta-Ihe que sua vida é uma sucessão de erros, que esteve muito doente (não diz de quê), relata uma viagem a Nova York,

https://periodicos.unifap.br/index.php/letras

Macapá, v. 6, n. I, Io semestre, 2016. 


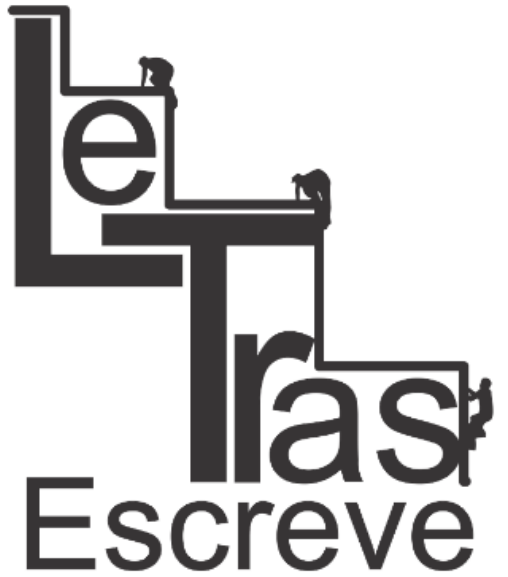

(ISSN 2238-8060)

semelhante a uma viagem ao inferno. $M$ fala um espanhol recheado de palavras francesas e seu rosto permanece inexpressivo ao longo do seu discurso. De vez em quando se permite um sorriso para acentuar o ridículo de uma situação, ou o que para ela parece ridículo e que de forma alguma o é, pensa B. (Bolaño, 2008, p. 84-5)

A sucessão de erros, a viagem e o espanhol misturado ao francês de forma alguma fazem daquela situação algo que possa ser visto como ridículo, ao menos para $\mathrm{B}$. Se um pouco antes em Paris, com a Luna park nas mãos, a cidade começou a lhe parecer um campo sem nada o que fazer, recorreu ao estudo de Henri Lefebvre. Agora em Bruxelas, $M$ lhe desperta o interesse. As dificuldades que se mostram de relance na história de $M$ parecem cumprir as condições para que B tenha tempo para ouvi-la. Ela chega a falar de sua adolescência, de suas idas e vindas de Nova York, mas B sente que ela tem algo a mais para lhe dizer, sem chegar a fazê-lo. Além disso, ela também esteve/está enferma.

A história de outra mulher também chama a atenção de $B$, despertando-o do sono literalmente. É mais uma história a Ihe despertar interesse e, de algum forma, tocá-lo.

\begin{abstract}
Naquela noite $B$ dorme com uma moça negra que fala enquanto dorme. Sua voz que B recorda suave e cadenciada, durante o sono é rouca e peremptória, como se em algum momento da noite (que escapou a B) se houvesse operado uma transformação nas cordas vocais da moça. Na verdade foi essa voz que lhe despertou como se lhe dessem uma martelada, depois, quando se dá conta de que é apenas a sua companheira que fala dormindo, permanece apoiado num cotovelo ouvindo-a por um instante, até que decide acordá-la. O que estava sonhando?, pergunta. A moça responde que sonhava com a mãe, morta havia pouco. Os mortos estão em paz, pensa B estirando-se na cama. A moça, como se adivinhasse seus pensamentos, replica que ninguém que já existiu no mundo está em paz. Nem nesta época, nem em nenhuma outra, diz com plena convicção. B sente vontade de chorar, mas em vez disso adormece. (Bolaño, 2008, p. 87-8)
\end{abstract}

A fala da moça sobre a impossibilidade de restar em paz faz com que $B$ tenha vontade de chorar. É óbvio que a iminência do choro lhe vem porque vê reconhecimento naquilo que a moça diz.

https://periodicos.unifap.br/index.php/letras

Macapá, v. 6, n. I, Io semestre, 2016. 
Ao invés de chorar, ele dorme. O conhecimento da enfermidade está posto, mas ele precisa continuar a sua busca pelo antídoto.

$\mathrm{M}$ conta a $\mathrm{B}$ que quando está triste costuma pegar o carro e seguir guiando sem saber ao certo para onde está indo. Apesar de não a doença de $M$ não ser especificada, na sequência do conto, podemos perceber na personagem certa necessidade de deslocarse em busca de algo que, também, não pode ser precisado.

No dia seguinte, M leva B até Masnuy, a cidade onde Lefebvre cresceu. Voltam a Bruxelas sem ter encontrado nada e B, a convite de $\mathrm{M}$, dorme na casa desta para economizar uma diária de hotel. Na casa de $M, B$ também ouve a amiga falar enquanto dorme. B volta a Paris no dia seguinte.

De Paris liga para $M$,

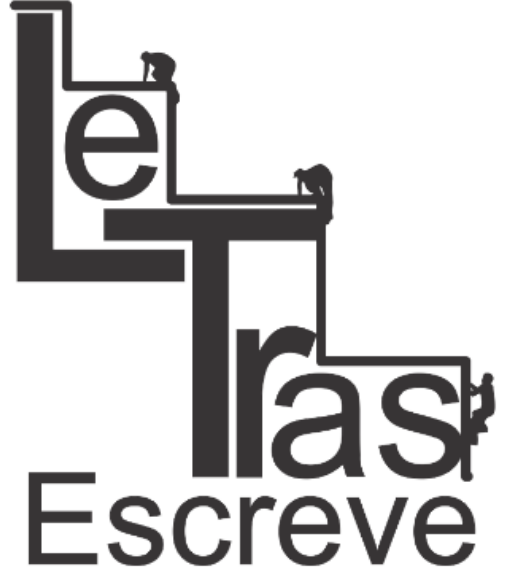

(ISSN 2238-8060)
Encontrou Henri Lefebvre?, pergunta M. Ainda deve estar dormindo, pensa B. Depois responde: não. M ri. Seu riso é bonito. Por que se interessa por ele?, pergunta sem parar de rir. Porque ninguém mais se interessa, responde $B$. $E$ porque era bom. Ato contínuo pensa: não devia ter dito isso. $E$ pensa: $M$ vai desligar. Cerra os dentes, involuntariamente seu rosto se contrai numa careta crispada. Mas M não desliga. (Bolaño, 2008, p. 93)

Ele esteve em busca de algo relacionado a Henri Lefebvre. Sem sabermos o que B buscava sobre Lefebvre, como talvez nem ele soubesse bem, podemos perceber que a história do escritor 0 interessa. Como chega a dizer no conto, ele parece buscar os poetas que foram "apagados do mapa". No movimento de busca por aquilo que parece ter perdido as coordenadas de referência, e que resulta num movimento em deriva, parece restarem histórias que precisam ser ouvidas e contadas.

Se "ninguém que já existiu no mundo está em paz", é possível dizer que, dependendo do grau de alienação no qual se vive, uns experienciam essa falta de paz mais do que outros. É notório o interesse de Bolaño por personagens que perecem ter sentido essa impossibilidade da paz de forma crua e decisiva. O caso de Henri

https://periodicos.unifap.br/index.php/letras Macapá, v. 6, n. I, Io semestre, 2016. 


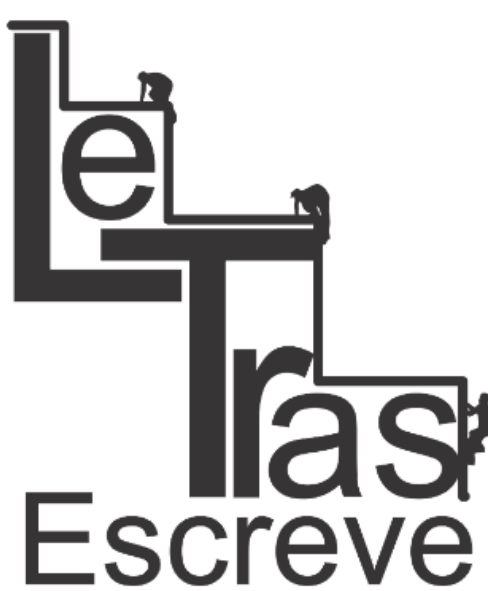

(ISSN 2238-8060)
Lefebvre não é uma novidade. Ulises Lima talvez seja o principal exemplo na obra de Bolaño, pois ele é um personagem inspirado em um poeta que pode ser considerado um modelo de artista invisível, marginalizado, que não é capaz de aderir a esferas sociais e que se condena a um retiro do mundo em nome da literatura. Além dele, podemos citar como exemplo Cesárea Tinajero - também de Os detetives... -, Benno Von Archomboldi - de 2666 - ou artistas desconhecidos como aquele nova-iorquino ${ }^{3}$ que vivia entre a mendicância e a vanguarda, fazendo performances que aumentam a intensidade da própria dor até que descobre que tem uma doença terminal e começa fazer um documentário do que seria a sua última performance: o artista documentou a vida que lhe restava até o momento derradeiro, o instante mais à beira do abismo em que o artista pôde alcançar.

Todos esses personagens parecem ter vivido aquela enfermidade da qual fala Bolaño. Todos parecem ter tomado plena consciência da derrota que os envolvia. Alvos de acentuado interesse por parte do chileno, eles parecem ter feito o sacrifício necessário à vida eleita pelo viajante baudelairiano, à vida que segue transitando por viagens, livros e sexo ou mesmo, à vida que exerce legitimamente o ofício da literatura e da arte em geral.

\section{Extraterritorialidade e antídoto contra a derrota}

Ignacio Echevarría, editor responsável pela obra póstuma de Bolaño, em um texto apresentado na presença do escritor - meses antes da morte deste -, investiga os motivos da influência do autor chileno sobre muitos outros escritores latino-americanos. "Bolaño extraterritorial" (Echevarría, 2008) traz como um importante motivo para isso a extraterritorialidade da figura do escritor, bem como de sua obra. Sobre o conceito de extraterritorialidade, Echevarría se vale das formulações/provocações teóricas do crítico americano

${ }^{3}$ Cf. Bolaño, 2012b, p. 212-213. 


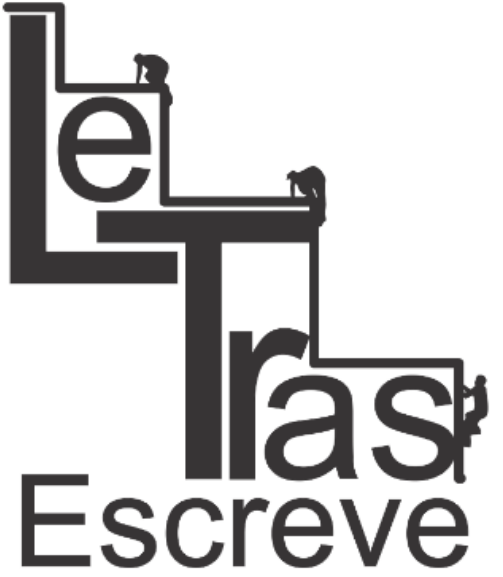

(ISSN 2238-8060)

George Steiner, que diz: sobre o nomadismo linguístico de alguns escritores; da pressão sobre a estabilidade linguística, sobre a consciência local e a nacional; sobre a condição de exilado partilhada pelos escritores contemporâneos - certo exílio permanente. ${ }^{4} \mathrm{O}$ editor aponta essas características em romances e poemas do chileno e na postura do próprio autor.

Os dois contos brevemente comentados acima possibilitam uma construção de sentido acerca de todo o impulso pela mobilidade e pelo deslocamento de perspectiva que advém desse mover-se constante. Além disso, vemos como o mover-se representa uma busca contínua por algo que não se sabe bem o que é e como tal movimento se detém quando há histórias que precisam ser narradas.

No conto "A neve", vemos dois chilenos em Barcelona, um deles foi exilado em Moscou depois do golpe de Estado no Chile. Além disso, Rogelio Estrada também precisou deixar a Rússia após determinados acontecimentos e, por algum tempo, circulou por alguns outros países da Europa. Quanto ao narrador, que nessa narrativa aparece muito pouco, sabemos também se tratar de um chileno que está em Barcelona.

Não só a questão do exílio permanente aparece nesse conto, a partir da ideia de extraterritorialidade, outro ponto é fundamental para a leitura desenvolvida aqui. Tendo como pressuposto a língua como parte central da concepção de mundo que determinada cultura possui e que línguas diversas preveem formas diferentes de formulação da realidade que envolvem o ser, não por acaso, a Rússia aparece como um primeiro destino após o Golpe do Chile. A Rússia é o local onde o ideário revolucionário se corrompeu, tornando-se uma ditadura implacável. O fato de Estrada ter morado na Rússia desde o fim da adolescência, e por muitos anos até ter que se mudar de lá, deixa sob tensão o eixo linguístico que o liga a terra natal, o espanhol do Chile.

${ }^{4}$ Cf. Echevarría, 2008, p. 438.

https://periodicos.unifap.br/index.php/letras Macapá, v. 6, n. I, Io semestre, 2016. 


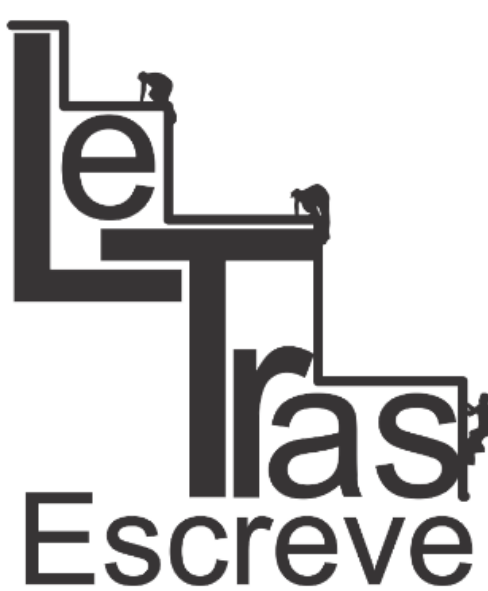

(ISSN 2238-8060)

Em certo momento que a faç̧ão cultural se reunia, falavam sobre o espírito latino e o espírito eslavo. Estrada conta como saía perdendo sobre a compreensão do espírito eslavo, o que, de certa maneira, mostra que alguma compreensão desse "espírito" ele possuía. Ao mesmo tempo que ele assume sentir falta de algo da Rússia, de algo no "mundo eslavo", sem saber exatamente o motivo da falta, e apesar de estar num país cuja língua oficial é o espanhol, é a outro chileno que Estrada recorre para contar a sua história.

Observamos, portanto, o multilinguismo do conceito de Steiner e do qual se vale Echevarría para entender Bolaño. O espanhol chileno é posto em contato com o espírito eslavo, mas é a outro chileno deslocado de sua terra natal que Estrada contará a sua história. Há o constante contato entre línguas, que se não é explícito na performance do idioma na narrativa, aparece na formulação da realidade que circunda o personagem, evidenciado, principalmente, pelas compreensões e incompreensões vividas por Estrada diante dos russos com quem se relaciona.

No conto "Vagabundo na França e na Bélgica", além do mover-se contínuo da personagem $\mathrm{B}$, aquele chamado de vagabundo, vemos uma personagem nascida além das fronteiras. É óbvio que $M$ nasceu em uma nação específica, no entanto ela é filha de um exilado chileno com uma ugandense que mora em Bruxelas e tem histórico de constantes idas e vindas à Nova York. Em um trecho supracitado, é possível ver como é o espanhol falado por $\mathrm{M}$, "um espanhol recheado de palavras francesas". A personagem $M$ seria, assim, uma outra face da extraterriorialidade mencionada por Echevarría, tanto pela constante movimentação entre as fronteiras bem como pela língua falada por ela. É o exílio permanente se materializando em personagem.

Quanto ao narrador de "A neve" e a personagem B de "Vagabundo na França...", é possível identificar elementos comuns que apontam ao impulso descrito no ensaio "Literatura + enfermedad = enfermedad". A cessão de espaço para a voz de Rogelio Estrada 


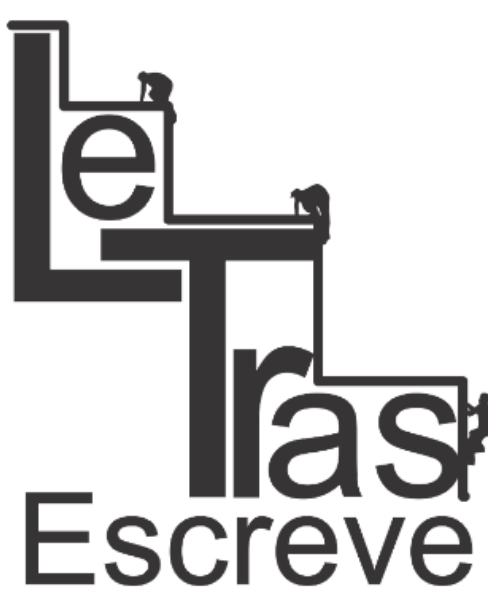

(ISSN 2238-8060) por parte do narrador - o já citado discurso indireto livre no qual a narrativa se estrutura - é o exercício da liberdade do viajante chileno que encontra em Barcelona alguém que pergunta se pode lhe contar um história. Como foi dito, a história cumpre a condicional imposta pelo narrador. Este, em viagem, fora de sua terra natal, não aparece mais no texto, pelo menos não claramente. O ignoto representado pelo percurso de outro chileno desperta tanto o interesse do narrador, que este se retira do texto abrindo espaço para que uma historia seja narrada. As narrativas pelas quais um ser se constrói, para si e para os outros, atuam como uma afirmação de si mesmo. Portanto, as narrativas também são uma forma de afirmação à vida de cada um. Seguir viagem, ouvir e narrar são partes do aprendizado poético do narrador, a busca por um antídoto à resignação do que quer que seja.

Esse narrador chileno em Barcelona, em sua movimentação, parece ouvir como se buscasse determinadas histórias que precisam ser contadas. "Vagabundo na França..." é outro exemplo disso. B recebe um dinheiro por um livro que ainda não escreveu e decide ir para a França. O início do conto mostra como ele vaga sem rumo pela França. Ele circula sem vontade e com indiferença. Quando encontra numa revista alguém sobre cuja escritura não conhece nada, o mesmo se dando sobre a vida desse escritor, ele se detém. A busca pela história de Lefebvre faz com que ele direcione seus esforços para tentar saber o que mais esse belga tinha a dizer. $\mathrm{Na}$ Bélgica, uma prostituta que fala dormindo também vira um ponto de parada nesse mover-se constante de um lugar a outro, de uma pessoa a outra. É uma parada para ouvir o que ela tem a dizer, mesmo dormindo. Ele é acordado pela voz da prostituta e a acorda para ouvir dela sobre o que estava sonhando.

A ida a Masnuy Saint-Jean, onde Lefebvre cresceu, não resultou em nenhum encontro, o que faz com que voltem a Bruxelas rapidamente. Nesta cidade só a vida e a movimentação de $M$ chamou-lhe a atenção. Depois de não encontrar nada sobre

https://periodicos.unifap.br/index.php/letras Macapá, v. 6, n. I, Io semestre, 2016. 


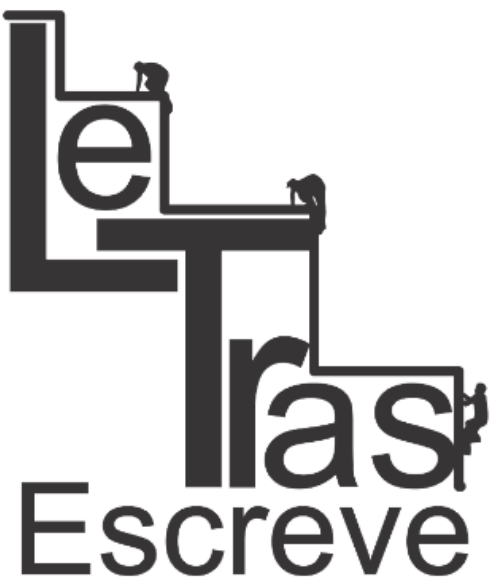

(ISSN 2238-8060)

Lefebvre e de ouvir o que M tinha a dizer, volta a Paris. Na cidade parisiense, liga para $\mathrm{M}$.

Todo o conto apresenta a movimentação sem destino prédefinido, intercalado por histórias que surgem em seu caminho. Nesse conto, as histórias que chamam a atenção do protagonista possuem algum tipo de desajuste, como se contivessem pontos de resistência àquela resignação apresentada no início desse texto. São histórias que demonstram aqueles personagens invisíveis, que parecem estar enfermos mas que, ainda assim, seguem tentando se equilibrar à beira do abismo onde escolheram buscar algum antídoto.

Assim, colocar-se em movimento é o próprio "sacrifício ritual", a que o narrador se refere no primeiro parágrafo de "Vagabundo na França...". O ritual do aprendizado poético, mas também, e em última estância, da busca por salvar-se. As histórias possuidoras de pontos de resistência à resignação cumprem as condicionais exigidas para que o narrador de "A neve" as escute. Há a consciência da derrota, mas ainda resta a vontade de salvar-se.

Ao comentar um texto de Canetti sobre Kafka, Bolaño diz,

\begin{abstract}
Supongo que quiero decir que Kafka comprendía que los viajes, el sexo y los libros son caminos que no llevan a ninguna parte, y que sin embargo son caminos por los que hay que internarse y perderse para volverse a encontrar o para encontrar algo, lo que sea, un libro, un gesto, un objeto perdido, para encontrar cualquier cosa, tal vez un método, con suerte: lo nuevo, lo que siempre ha estado allí. (Bolaño, 2012b, p. 158)
\end{abstract}

Onde o narrador vai ele tem alguém para ouvir, alguém que precisa narrar, assim se estruturam as narrativas dos contos analisados. É o tratamento narrativo necessário para dar conta desse universo em que seguir viagem é uma necessidade.

A composição narrativa estruturada na cessão de voz diante de alguém que quer narrar a sua experiência do deslocamento e um personagem cuja motivação é seguir viagem e ouvir o que algumas

https://periodicos.unifap.br/index.php/letras

Macapá, v. 6, n. I, Io semestre, 2016. 
pessoas precisam dizer representam, respectivamente, a viagem como única possibilidade perante a derrota e o impulso pela narrativa como a busca pelo novo. A viagem-sacrifício ritual e a condenação ao narrar são o próprio ato de caminhar em direção ao abismo, que o único lugar onde poderá ser encontrado a cura para a enfermidade. Nos contos, caminhar pelo desconhecido e em busca do novo é o próprio impulso pela narrativa de certas histórias.

\section{Referências bibliográficas}

Baudelaire, Charles. As flores do mal. Trad. Ivan Junqueira. Rio de Janeiro: Nova Fronteia, 2006.

Bolaño, Roberto. 2666. Trad. Eduardo Brandão. São Paulo: Companhia das Letras, 2010.

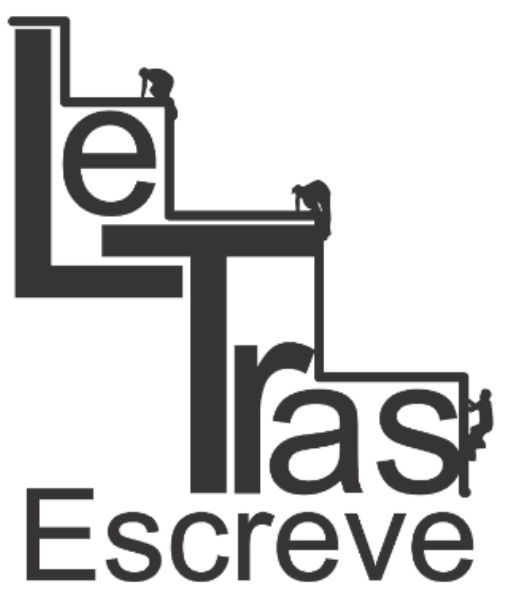

(ISSN 2238-8060)

Bolaño, Roberto. Chamadas telefônicas. Trad. Eduardo Brandão. São Paulo: Companhia das Letras, 2012a.

Bolaño, Roberto. El gaucho insufrible. Barcelona: Anagrama, 2012b.

Bolaño, Roberto. Entre paréntesis. Barcelona: Anagrama, 2013.

Bolaño, Roberto. Os detetives selvagens. Trad. Eduardo Brandão São Paulo: Companhia das Letras, 2006.

Bolaño, Roberto. Putas assassinas. Trad. Eduardo Brandão. São Paulo: Companhia das Letras, 2008.

Echevarría, Ignacio. "Bolaño Extraterritorial”. In: SOLDÁN, Edmundo Paz (Org.). Bolaño Salvage. Barcelona: Editorial Candaya, 2008.

Recebido em 10/06/2016. Aprovado em 20/07/2016. 